\title{
Recycling Nickel Slag by Aluminum Dross: Iron-extraction and Secondary Slag Stabilization
}

\author{
Guangzong ZHANG, Nan WANG, ${ }^{*}$ Min CHEN and Yanqing CHENG \\ School of Metallurgy, Northeastern University, Shenyang, Liaoning, 110819 China. \\ (Received on March 20, 2019; accepted on August 28, 2019; J-STAGE Advance published date: \\ October 24, 2019)
}

\begin{abstract}
Nickel slag is a metallurgical solid waste from nickel refineries, which can be recycled as one of excellent secondary sources due to valuable iron contents. In this work, the approach of recycling nickel slag by aluminum dross was proposed, and the processes of network modification of slags and reduction were successively investigated at $1773 \mathrm{~K}$. Upon the thermodynamic calculations, $\mathrm{CaO}$ was chosen as the modifier in order to obtain a higher activity of ' $\mathrm{FeO}$ ', and basicity of the modified slag was determined as 1.0. Element mapping analysis of the modified slag showed that 'FeO' had been separated from the structure of nickel slag. After aluminothermic reduction for $120 \mathrm{~min}$, the recovery degree of iron and copper was $94.35 \%$ and $97.89 \%$, respectively. In addition, the secondary slag stabilization was discussed, and the utilization of the produced Fe-Cu alloy and the secondary slag was analyzed.
\end{abstract}

KEY WORDS: recycling; nickel slag; aluminum dross; iron-exaction; secondary slag stabilization.

\section{Introduction}

Nickel slag is a metallurgical solid waste from the nickel refineries, which can be recycled as one of excellent secondary sources due to the amounts of iron contents. The iron content can reach up to $50 \mathrm{wt} \%{ }^{1,2)}$ With the growing demand of nickel products nowadays, nickel slag is discharged continuously. It is estimated that 6-16 tons of nickel slag in flash smelting process are generated per ton of nickel produced. ${ }^{3,4)}$ Taking Jinchuan Group Co. Ltd (Yinchuan, China) as an example, $\sim 160$ tons of granulated nickel slag are output annually and more than 33 million tons of the nickel slag have been accumulated to date. Generally, these waste streams are utilized in sectors like road construction, fertilizer and cement manufacture, while the rest are stockpiled in heaps or controlled in landfills. ${ }^{5}$ ) The negligent disposal raises serious environmental concerns and valuable resources waste. ${ }^{6,7)}$ Therefore, effective technology for iron extraction from the nickel slag is deeply essential to the sustainable development of resource and environment.

Hydrometallurgy is regarded as an effective method to extract metals from waste slags including flotation, leaching, roasting followed by leaching and bioleaching. ${ }^{8,9)}$ Nevertheless, its production efficiency is limited and the disposal of waste water produced is difficult. ${ }^{10)}$ Compared with the hydrometallurgical processes, liquid waste would not be generated by pyrometallurgical methods. Moreover, considerable sensible heat contained in the molten nickel slag can used adequately. ${ }^{11)}$ Therefore, pyrometallurgical methods are used mainly for slag treatment in today's recovery of

\footnotetext{
* Corresponding author: E-mail: wangn@smm.neu.edu.cn DOI: https://doi.org/10.2355/isijinternational.ISIJINT-2019-173
}

base and precious metals, and in the past years, extensive researches have been carried out. ${ }^{12-16)}$ Although most of the works are focused on the copper and other waste slags, the thermal reduction techniques they used can still provide lots of valuable ideas for recycling nickel slag.

On the one hand, reduction method was generally adopted in the recovery process. ${ }^{17-21)}$ Coke and carbon powder were used as the reducing agent, and fluxes such as $\mathrm{CaO}, \mathrm{CaF}_{2}$ and $\mathrm{CaCO}_{3}$ were added as the constituent regulators to modify the properties of the residual melt. Apart from the carbothermal reduction process, aluminothermic reduction method in waste copper slag was also investigated by Heo et $a l .{ }^{14)}$ Even though the clean secondary slag (by-product after the aluminothermic reduction) could be produced, high purity aluminum shots acting as the reducing agent were not economic. On the other hand, the oxidation method was also studied by Wang et al. ${ }^{22,23)}$ Oxygen with a fixed flow rate was inlet into slag system to oxidize the iron-bearing phase from fayalite to magnetite, followed by the magnetic separation and reduction process.

Learning from the treatment techniques for cooper slag, aluminothermic reduction process is adopted for the iron recovery from nickel slag. However, aluminum dross is chosen as the substitution of pure aluminum shot. Aluminum dross is an inevitable metallurgical solid waste from aluminum industries, e.g. electrolytic or cast aluminum industries. ${ }^{24,25)}$ Typically, the aluminum dross mainly consists of oxides $\mathrm{Al}_{2} \mathrm{O}_{3}, \mathrm{SiO}_{2}, \mathrm{MgO}, \mathrm{CaO}$ and elementary substance $\mathrm{Al}$, and the content of $\mathrm{Al}$ can reach up to $30-35 \mathrm{wt} \%$, signifying an exciting new alternative source of aluminum. About $25-50 \mathrm{~kg}$ of aluminum dross is released per ton of aluminum produced, which is also piled up in the open-air resulting in serious environmental problems. ${ }^{26)}$ Compared 
with the processes aforementioned, the current innovative approach has the following characteristics:

(1) Short process can be acquired and considerable physical heat in molten nickel slag can be used sufficiently, which is out of reach to oxidation process. ${ }^{27,28)}$

(2) Carbothermal reduction process is an endothermic reaction, the main drawback of this technology is its high energy consumption. ${ }^{29)}$ It was estimated that about $156 \mathrm{~kJ}$ heat would be consumed per kilogram of Fe generated. Alternatively, the aluminothermic reduction is considered as a self-sustaining method due to the generation of essential heat energy. ${ }^{30)}$

(3) Reduction by aluminum dross rather than by the high purity aluminum shots is economical as well as environmentally friendly.

In our previous works, we have discussed the viscosity evolution of slags during the reduction process, and a better kinetic condition could be obtained. ${ }^{31,32)}$ The purpose of this paper is to investigate the feasibility of the innovative approach. As mentioned above, modifier (or flux) is of significance to the treatment process. It can not only separate the ' $\mathrm{FeO}$ ' and increase its activity in nickel slag, but also facilitate the secondary stabilization. Therefore, the network modification process is firstly studied upon the thermodynamics analysis, and mechanism underlying the role of the modifier is investigated. Additionally, the reduction behavior is studied to take a knowledge of aluminothermic reduction by aluminum dross. What's more, the reduced products and secondary slag stabilization are analyzed, respectively.

\section{Experimental}

\subsection{Materials}

Nickel slag used in this experiment was the quenched flash smelting slag, which was supplied by a domestic nickel plant. The aluminum dross was collected from an aluminum enterprise. The compositions of these two solid wastes were listed in Table 1. The iron content containing in nickel slag reached up to $51.31 \mathrm{wt} \%$, simultaneously, the content of metallic Al in aluminum dross was determined as 33.14 wt $\%$ by titration method. Due to the difference in activity, redox reactions can occur between different metal ions. As indicated in Eqs. (1)-(2), $\mathrm{FeCl}_{3}$ was adopted to react with aluminum dross, then $\mathrm{KMnO}_{4}$ was used to calibrate the amount of $\mathrm{Fe}^{2+}$ generated from Eq. (1). According to the consumption of $\mathrm{KMnO}_{4}$, the content of metallic $\mathrm{Al}$ was calculated. The repeated measurements were carried out at least three times, and the mean value was finally determined.

$$
\begin{array}{r}
\mathrm{Al}+3 \mathrm{Fe}^{3+}=\mathrm{Al}^{3+}+3 \mathrm{Fe}^{2+} \\
\mathrm{MnO}^{4-}+8 \mathrm{H}^{+}+5 \mathrm{Fe}^{2+}=\mathrm{Mn}^{2+}+5 \mathrm{Fe}^{3+}+4 \mathrm{H}_{2} \mathrm{O}
\end{array}
$$

The detection of $\mathrm{Na}_{2} \mathrm{O}$ was carried out by X-Ray Fluorescence (XRF, ZSX100e, Rigaku, Japan). A ZSX100e spectrometer was applied to determine the chemical compositions of the slag system, and the measurement range of which was from 5 ppm to $100 \%$. Each element has a specific wavelength of the fluorescent ray, and the intensity of the fluorescent ray is proportional to its concentration. After the intensity detection of elemental $\mathrm{Na}$ and the corrections of matrix effect, spectral overlap and peak-position background, the content of $\mathrm{Na}$ was obtained. Thereafter, the content of $\mathrm{Na}_{2} \mathrm{O}$ was calculated. As for the AlN content, pulsed infrared and thermal-conductive method was applied in analyzing the content of elemental $\mathrm{N}$ in dross. Oxygen, nitrogen and hydrogen combined analyzer $(\mathrm{ONH}$ 836, LECO, USA) was adopted, the $\mathrm{N}$ content range of which covers from $0.05 \%$ to $3.0 \%$. The analysis power was $5.0 \mathrm{~kW}$, and the minimum integration time was $45 \mathrm{~s}$. The content of AlN in dross was calculated based on the content of elemental N. Additionally, the process conditions without soluble-salt addition induced the lower contents of $\mathrm{F}, \mathrm{K}$ and $\mathrm{Cl}(\sim 0.14 \%)$ in aluminum dross, which had been ignored in this work.

Figure 1 showed the characterization of nickel slag and aluminum dross. In order to take an understanding of the crystal phases in materials, X-ray diffraction (XRD, D8 Advance, Bruker AXS Gmbh, Germany) pattern was conducted and the results were shown in Figs. 1(a) and 1(c). XRD pattern was operated at $40 \mathrm{kV}$ and $40 \mathrm{~mA}$ with $\mathrm{Cu}$ $\mathrm{K} \alpha$ radiation, and the pattern data were collected in the 2 -theta range between $10^{\circ}$ and $90^{\circ}$. It could be observed that minerals in nickel slag were fayalite $\left(2 \mathrm{FeO} \cdot \mathrm{SiO}_{2}\right)$ and hortonolite $\left(2(\mathrm{MgO}, \mathrm{FeO}) \cdot \mathrm{SiO}_{2}\right)$, and $2 \mathrm{FeO} \cdot \mathrm{SiO}_{2}$ were the dominant phase. Figure 1(b) presented the scanning electron microscope (SEM, Zeiss ULTRA 55) image of nickel slag. Element distributions of points $\mathrm{A}, \mathrm{B}$ and $\mathrm{C}$ in the image were analyzed by energy dispersive spectrometer (EDS), and the results were listed in Table 2. From the atomic ratio of elemental $\mathrm{Fe}, \mathrm{Mg}$ and $\mathrm{O}$, points $\mathrm{A}$ and $\mathrm{B}$ represented the hortonolite phases with clumpy and layered structure, respectively. The difference in the structure lied in the different contents of elemental $\mathrm{Fe}$ and $\mathrm{Mg}$. While, the result of point $\mathrm{C}$ indicated that the matrix of nickel slag was fayalite phase. As shown in Figs. 1(c) and 1(d), aluminum dross was characterized by the metallic Al and other oxides, keeping a good accordance with the chemical analysis. The particle size distribution of dross was analyzed by Master sizer 2000 (Malvern, England), and the mean size was $839.365 \mu \mathrm{m}$.

\subsection{Thermodynamic Analysis}

In conjunction with the results of XRD and SEM, 'FeO' in nickel slag was always presenting as the form of silicate phases. Since $\mathrm{SiO}_{2}$ would act as the network former in slag structure, either the fayalite or hortonolite had a highly polymerized structure. ${ }^{33-35)}$ Therefore, modifier was essential to adjust nickel slag to separate ' $\mathrm{FeO}$ ' and to obtain a higher activity. ${ }^{36,37)}$ As studied by Li et al., network modifi-

Table 1. Chemical compositions of nickel slag and aluminum dross (wt\%).

\begin{tabular}{ccccccccccccc}
\hline Compositions & $‘ \mathrm{FeO}$ & $\mathrm{CaO}$ & $\mathrm{MgO}$ & $\mathrm{SiO}_{2}$ & $\mathrm{Al}_{2} \mathrm{O}_{3}$ & $\mathrm{Al}$ & $\mathrm{AlN}$ & $\mathrm{Na}_{2} \mathrm{O}$ & $\mathrm{Ni}$ & $\mathrm{Co}$ & $\mathrm{Cu}$ & $\mathrm{S}$ \\
\hline Nickel slag & 51.31 & 3.58 & 8.41 & 31.60 & - & - & - & - & 0.16 & 0.08 & 0.22 & 1.20 \\
Aluminum dross & - & 2.04 & 6.97 & 10.12 & 40.83 & 33.14 & 4.85 & 2.05 & - & - & - & - \\
\hline
\end{tabular}



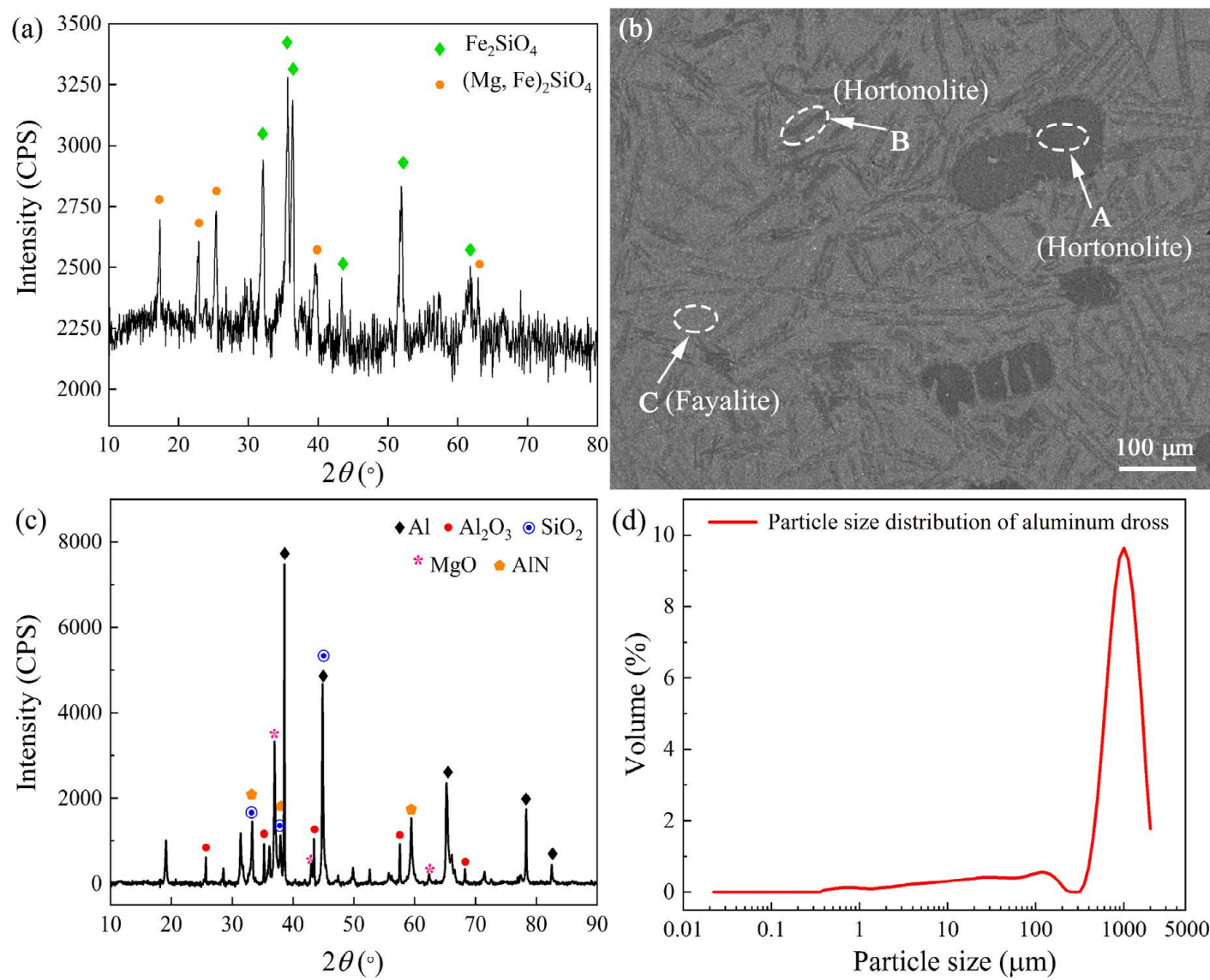

Fig. 1. Characterization of nickel slag and aluminum dross. (a) XRD pattern of nickel slag; (b) SEM microphotograph of nickel slag; (c) XRD pattern of aluminum dross; (d) particle size distribution of aluminum dross. (Online version in color.)

Table 2. EDS results of element content in nickel slag (atomic ratio, \%).

\begin{tabular}{ccrrrl}
\hline \multirow{2}{*}{ Point } & \multicolumn{4}{c}{ Elements } & Phases \\
\cline { 2 - 5 } & $\mathrm{Fe}$ & $\mathrm{Mg}$ & \multicolumn{1}{c}{$\mathrm{Si}$} & $\mathrm{O}$ & \\
\hline $\mathrm{A}$ & 13.14 & 20.01 & 17.07 & 49.78 & Hortonolite, $2(\mathrm{MgO}, \mathrm{FeO}) \cdot \mathrm{SiO}_{2}$ \\
B & 17.11 & 15.43 & 19.20 & 48.26 & Hortonolite, $2(\mathrm{MgO}, \mathrm{FeO}) \cdot \mathrm{SiO}_{2}$ \\
$\mathrm{C}$ & 24.71 & 3.21 & 22.49 & 49.60 & Fayalite, $2 \mathrm{FeO} \cdot \mathrm{SiO}_{2}$ \\
\hline
\end{tabular}

cation of slag had been widely applied into improving slag properties during processes of waste treatment, such as disintegration, cementitious reactivity, heavy metal leaching and iron component recovery. ${ }^{38,39)}$ Appropriate modification method would benefit the extraction of valuable metals from molten slag and the transition of secondary slag into valueadded materials.

Thermodynamic analysis for slag made it possible to predict the proper modifier. The standard Gibbs free energy $\left(\Delta G^{\theta}\right)$ of related reactions was presented as Eqs. (3)-(8), which was calculated by the thermodynamic software FactSage 7.0 (CRCT ThermFact, Inc., Montreal, Canada). ${ }^{40)}$ During the calculation process, phase (solid or liquid) of each compound was determined as the stable one under the current temperature. Figure $\mathbf{2}$ showed the relationship between $\Delta G^{\theta}$ and temperature. With temperature increasing from 273 to $1873 \mathrm{~K}$, the positivity for Eq. (3) signified the reaction would not take place under the standard state. On the contrary, the values of $\Delta G^{\theta}$ for Eqs. (6)-(8) were all

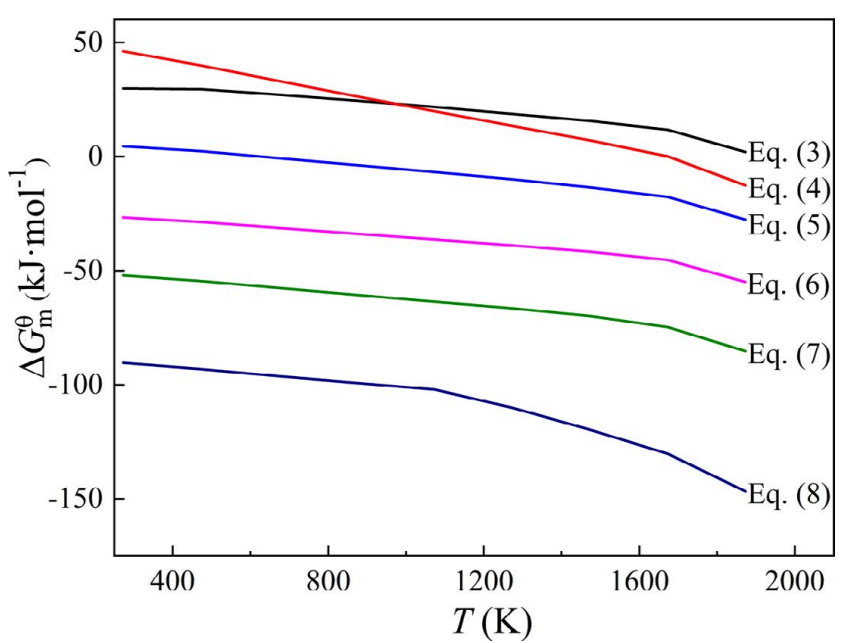

Fig. 2. Relationship between $\Delta G^{\theta}$ and temperature. (Online version in color.)

negative over the temperature range, indicating the thermodynamic possibilities of these four reactions. The lower values for Eqs. (7) and (8) suggested the stronger binding ability between $\mathrm{CaO}$ and $\mathrm{SiO}_{2}$, and $\mathrm{CaO}$ should be the optimum modifier in comparison with $\mathrm{MgO}$ and $\mathrm{Al}_{2} \mathrm{O}_{3}$.

$$
\mathrm{Al}_{2} \mathrm{O}_{3}(\mathrm{~s})+2 \mathrm{FeO} \cdot \mathrm{SiO}_{2}(\mathrm{~s} / \mathrm{l})=\mathrm{Al}_{2} \mathrm{O}_{3} \cdot \mathrm{SiO}_{2}(\mathrm{~s})+2 \mathrm{FeO}(\mathrm{s} / \mathrm{l})
$$




$$
\begin{aligned}
3 / 2 \mathrm{Al}_{2} \mathrm{O}_{3}(\mathrm{~s})+2 \mathrm{FeO} \cdot \mathrm{SiO}_{2}(\mathrm{~s} / \mathrm{l})= & 3 / 2 \mathrm{Al}_{2} \mathrm{O}_{3} \cdot \mathrm{SiO}_{2}(\mathrm{~s}) \\
& +2 \mathrm{FeO}(\mathrm{s} / \mathrm{l})
\end{aligned}
$$

$\mathrm{MgO}(\mathrm{s})+2 \mathrm{FeO} \cdot \mathrm{SiO}_{2}(\mathrm{~s} / \mathrm{l})=\mathrm{MgO} \cdot \mathrm{SiO}_{2}(\mathrm{~s} / \mathrm{l})+2 \mathrm{FeO}(\mathrm{s} / \mathrm{l})$

$2 \mathrm{MgO}(\mathrm{s})+2 \mathrm{FeO} \cdot \mathrm{SiO}_{2}(\mathrm{~s} / \mathrm{l})=2 \mathrm{MgO} \cdot \mathrm{SiO}_{2}(\mathrm{~s})+2 \mathrm{FeO}(\mathrm{s} / \mathrm{l})$

$$
\mathrm{CaO}(\mathrm{s})+2 \mathrm{FeO} \cdot \mathrm{SiO}_{2}(\mathrm{~s} / \mathrm{l})=\mathrm{CaO} \cdot \mathrm{SiO}_{2}(\mathrm{~s} / \mathrm{l})+2 \mathrm{FeO}(\mathrm{s} / \mathrm{l})
$$

$$
2 \mathrm{CaO}(\mathrm{s})+2 \mathrm{FeO} \cdot \mathrm{SiO}_{2}(\mathrm{~s} / \mathrm{l})=2 \mathrm{CaO} \cdot \mathrm{SiO}_{2}(\mathrm{~s})+2 \mathrm{FeO}(\mathrm{s} / \mathrm{l})
$$

\subsection{Target Basicity of Modified Slag}

Compositions of the modified slags (mixture of nickel slag and $\mathrm{CaO}$ ) with different slag basicities (mass ratio of $\mathrm{CaO} / \mathrm{SiO}_{2}$ in slag system) were plotted in Fig. 3. ${ }^{40)} \mathrm{As}$ shown in Figs. 3(a) and 3(b), $\mathrm{CaO}-\mathrm{FeO}-\mathrm{SiO}_{2}-\mathrm{MgO}$ and $\mathrm{CaO}-\mathrm{Al}_{2} \mathrm{O}_{3}-\mathrm{SiO}_{2}-\mathrm{MgO}$ were the corresponding slag systems before and after the reduction process, respectively. Point A represented the composition of nickel slag, while points $\mathrm{B}, \mathrm{C}, \mathrm{D}, \mathrm{E}$ and $\mathrm{F}$ represented the compositions of the modified slag with basicities of $0.5,0.75,1.0,1.25$ and 1.5 , respectively. After the reduction reaction, these points evolved to be points A' to F' correspondingly. According to the isothermals, the influences of $\mathrm{CaO}$ addition on the evolution of the melting points of slags were different.

Effects of slag basicity on the melting points of slags and the activity of 'FeO' were shown in Fig. 4, where Fig. 4(a) showed the melting points of initial and secondary slags under different slag basicities. ${ }^{40)}$ Here, the initial slag was defined as the slag before aluminothermic reduction. For the initial slags, the melting points changed non-monotonically with addition of $\mathrm{CaO}$ and exhibited a minimum value of $1386 \mathrm{~K}$ at basicity of 0.5 . As studied by Lee et al., $\mathrm{CaO}$ addition changed the equilibrated primary phase of the slag, and the increment of melting points of slags was attributed to the enhanced crystallization effect by stoichiometric compound. ${ }^{35,41)}$ In practice, the discharging temperature of nickel slag varied from 1573 to $1633 \mathrm{~K}$. If basicity of the modified slag was higher than 1.25 , the melting point of initial slag was higher than the discharging temperature. Therefore, the basicity of modified slag should be controlled lower than 1.25 to guarantee a liquid state. Alternatively, when the basicity of modified slag was lower than 0.75 , the melting point of secondary slag was higher than 1820
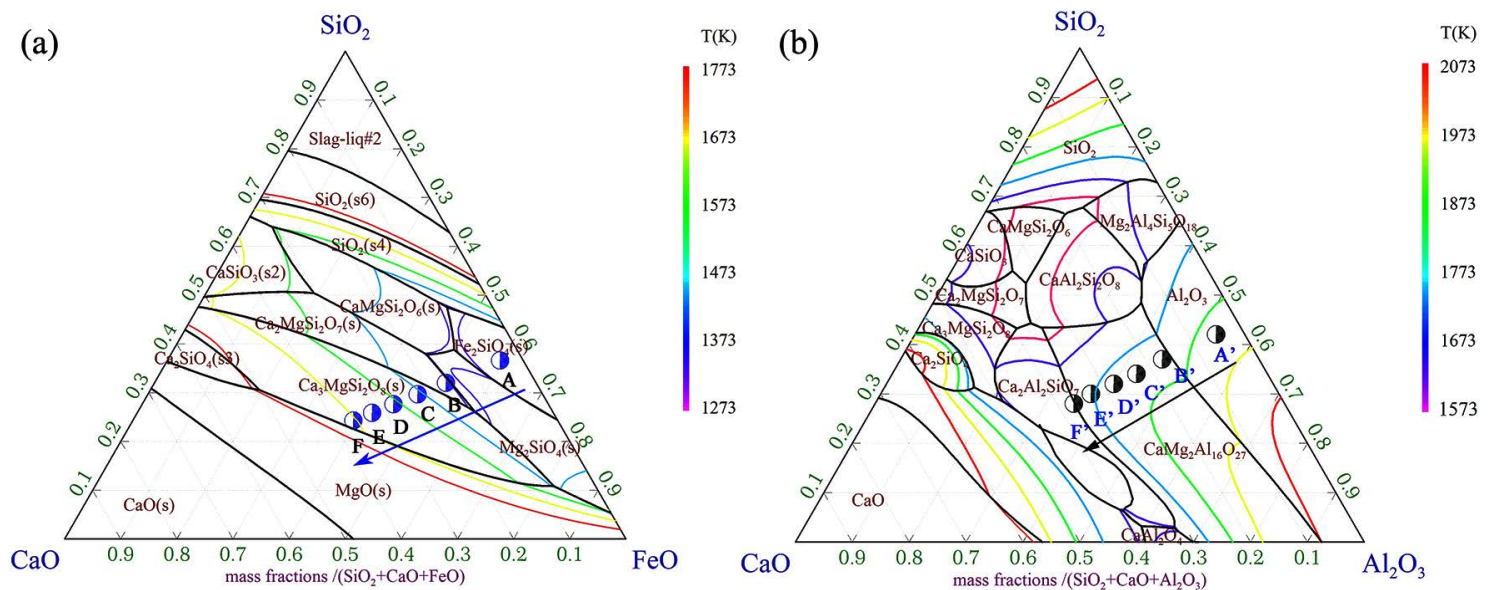

Fig. 3. Phase diagram of (a) $\mathrm{CaO}-\mathrm{FeO}-\mathrm{SiO}_{2}-\mathrm{MgO}$ system; (b) $\mathrm{CaO}-\mathrm{Al}_{2} \mathrm{O}_{3}-\mathrm{SiO}_{2}-\mathrm{MgO}$ system. (Online version in color.)
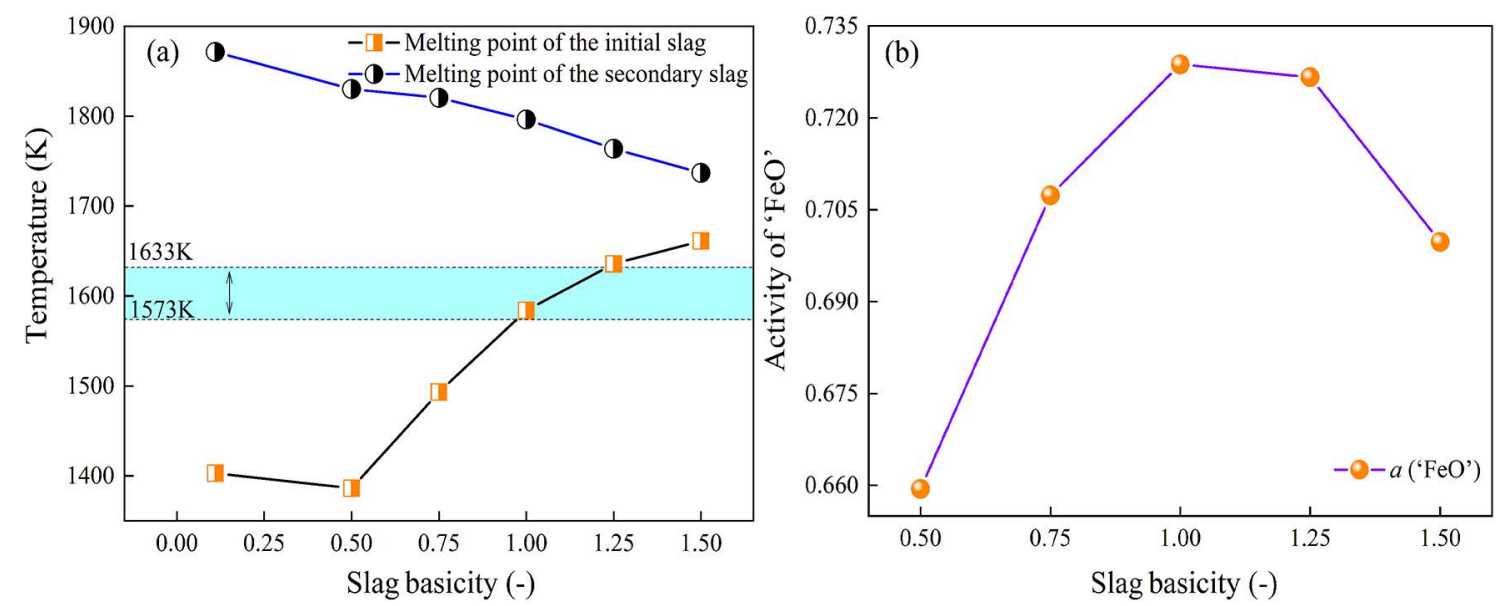

Fig. 4. Effect of slag basicity on (a) melting points of the initial and secondary slags; (b) activity of 'FeO'. (Online version in color.) 
$\mathrm{K}$, suggesting a higher reduction temperature. In terms of energy conservation, the basicity of modified slag lower than 0.75 was not advisable.

Figure 4(b) represented the relationship between activity of 'FeO' ( $a\left({ }^{\prime} \mathrm{FeO}\right.$ ')) and slag basicity. $a$ ('FeO') increased first then decreased, and the maximum value of 0.729 was obtained at the basicity of 1.0. Combining with the evolution of melting points of slags, the proper basicity of modified slag should be 1.0 .

\subsection{Experimental Procedure and Equipment}

Modification experiment was carried out firstly. Nickel slag and the $\mathrm{CaO}$ powder were mixed, where $\mathrm{CaO}$ powder was prepared by calcining the reagent grade $\mathrm{CaCO}_{3}$ powder (purity $\geq 99.9 \%$ ) at $1173 \mathrm{~K}$. The appropriate amount of $\mathrm{CaO}$ was added to guarantee basicity of the modified slag of 1.0. The experiment was performed using an electric tubular furnace, as shown in Fig. 5.

It was equipped with six U-shape $\mathrm{MoSi}_{2}$ heaters. After the intensive mixing, 20 grams of samples were charged into a magnesia crucible (outer diameter: $30 \mathrm{~mm}$, inner diameter: $24 \mathrm{~mm}$, height: $45 \mathrm{~mm}$ ), which was then placed into the furnace and kept in the high temperature zone. The slag temperature was precisely controlled by a PtRh30-PtRh6 thermocouple, the deviation of which was within $\pm 2 \mathrm{~K}$. The experimental temperature was determined as $1773 \mathrm{~K}$ in considerations of the melting point of the secondary slag and the exothermic characteristic of aluminothermic reaction. After heated to the required temperature, the mixture was held at $1773 \mathrm{~K}$ for $30 \mathrm{~min}$ to ensure the formation of homogeneous molten slag. In the whole procedure, high purity argon with the flow rate of $0.5 \mathrm{~L} \cdot \mathrm{min}^{-1}$ was guaranteed to avoid the oxidation of slag components. Then, the crucible with molten slag was taken out rapidly and quenched in liquid nitrogen, waiting for the examination by SEM equipped with EDS.

For the aluminothermic reduction experiment, the technological procedure was similar. After the modified slag was homogeneous at $1773 \mathrm{~K}$, a certain proportion of aluminum dross was added into the molten slag by a quartz tube. In the present experiment, $\mathrm{Al} /{ }^{\prime} \mathrm{FeO}$ ' ratio of 0.67 was determined upon the reduction reaction Eq. (9). ${ }^{42)}$

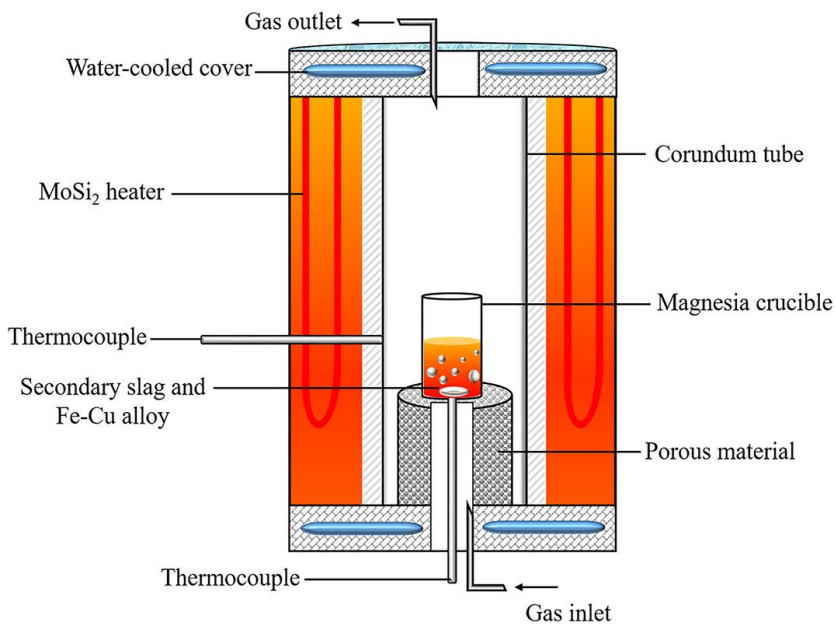

Fig. 5. Schematic diagram of experimental setup. (Online version in color.)

$$
\begin{aligned}
& \mathrm{Al}(\mathrm{l})+1.5 \mathrm{FeO}(\mathrm{l})=1.5 \mathrm{Fe}(\mathrm{l})+0.5 \mathrm{Al}_{2} \mathrm{O}_{3}(\mathrm{~s}), \\
& \Delta G^{\theta}=-444428.5+89.55 \mathrm{~T} \mathrm{~J} \times \mathrm{mol}^{-1}
\end{aligned}
$$

After different reaction time $(5,10,30,60$ and 120 min, respectively), the crucible was taken out quickly and quenched in liquid nitrogen. Based on our pre-experiment $(\mathrm{MgO}=6.84-9.48 \mathrm{wt} \%$ in preliminary slag composition) and other related researches, ${ }^{14,41)}$ the magnesia crucible could keep a perfect condition after reaction time of $60 \mathrm{~min}$, and the reaction time of $120 \mathrm{~min}$ was designed to investigate the variation of recovery degree of reduced product. The sample microstructure was investigated by SEM and the compositions of the reduced product were analyzed by XRF.

\section{Results and Discussion}

\subsection{Element Mapping Analysis of the Modified Slag}

Figure 6 presents the element mapping of the modified slag. It can be found that iron element has been separated from the silicate structure totally and exists as the free ' $\mathrm{FeO}$ ' in slag. Simultaneously, $\mathrm{CaO}$ is mostly associated with the $\mathrm{SiO}_{2}$, implying the sufficient reaction between $\mathrm{CaO}$ and fayalite. Table 3 lists the EDS results of phases in the modified slag. The atomic ratios of points $\mathrm{D}$ and $\mathrm{E}$ illustrate that the oxides ' $\mathrm{FeO}$ ' and $\mathrm{MgO}$ are surrounded by the calcium silicate $\left(\mathrm{CaO} \cdot \mathrm{SiO}_{2}\right)$ and dicalcium silicate $\left.(2 \mathrm{CaO} \cdot \mathrm{SiO})_{2}\right)$. Based on Eqs. (5)-(8) and the distribution of elemental $\mathrm{Mg}$, Fe and $\mathrm{Si}$, it could concluded that the stabilities of fayalite and hortonolite are weaker than those of $\mathrm{CaO} \cdot \mathrm{SiO}_{2}$ and $2 \mathrm{CaO} \cdot \mathrm{SiO}_{2}$. Therefore, modification by $\mathrm{CaO}$ is of significance to adjust the nickel slag to obtain a higher $a$ ('FeO').
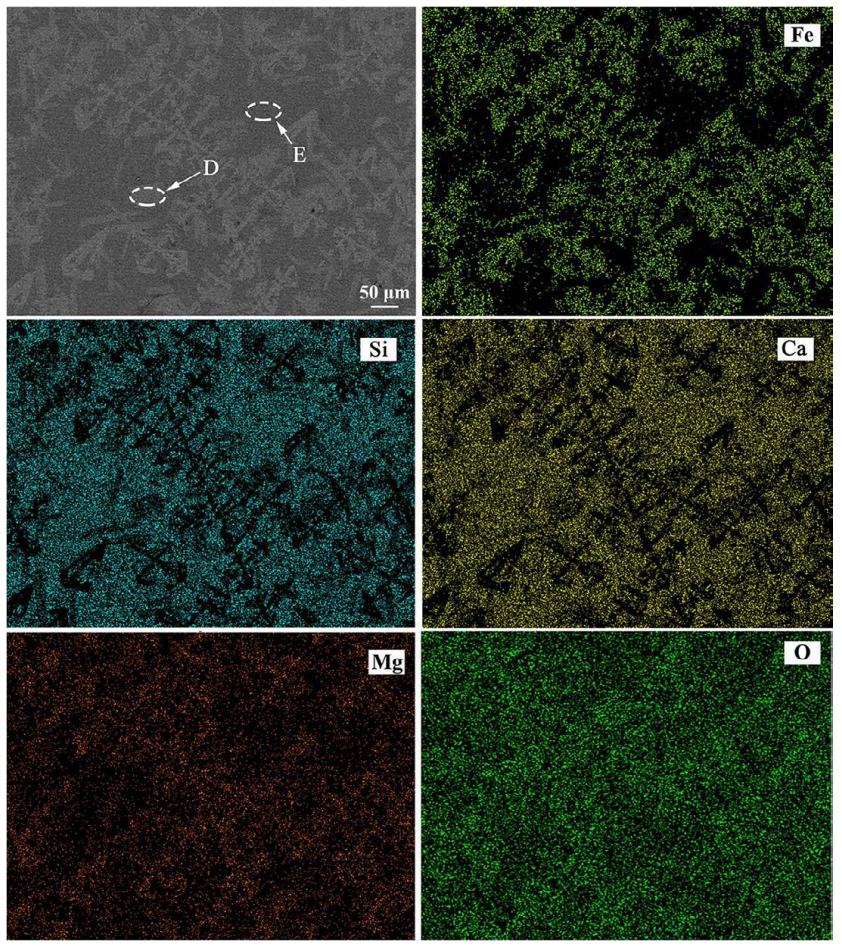

Fig. 6. Element mapping of the modified slag. (Online version in color.) 
Table 3. EDS results of phases in the modified slag (atomic ratio, $\%)$.

\begin{tabular}{crrrrrc}
\hline \multirow{2}{*}{ Point } & \multicolumn{5}{c}{ Elements } & Phases \\
\cline { 2 - 6 } & \multicolumn{1}{c}{$\mathrm{Fe}$} & \multicolumn{1}{c}{$\mathrm{Mg}$} & \multicolumn{1}{c}{$\mathrm{Ca}$} & \multicolumn{1}{c}{$\mathrm{Si}$} & $\mathrm{O}$ & \\
\hline $\mathrm{D}$ & 27.52 & 22.47 & 0.08 & 0.12 & 49.81 & $\mathrm{Fe}(\mathrm{Mg}) \mathrm{O}$ \\
$\mathrm{E}$ & 0.00 & 0.02 & 20.58 & 19.61 & 59.79 & $\mathrm{CaO} \cdot \mathrm{SiO}_{2}, 2 \mathrm{CaO} \cdot \mathrm{SiO}_{2}$ \\
\hline
\end{tabular}

\subsection{Aluminothermic Reduction Results}

\subsubsection{Iron Recovery}

Figure 7 shows the images of the reduced product and secondary slag after reaction for $120 \mathrm{~min}$. Iron ingot with the dimension of $10 \mathrm{~mm}$ has been coalesced at the bottom of crucible. Moreover, many visible iron droplets have been generated and dispersed in the porous slag or adhered to the inner surface of the crucible.

\subsubsection{Slag Microstructure after Reduction Reaction}

Figure 8 represents the slag microstructure after reduction reaction for $120 \mathrm{~min}$. The produced iron particles with various shapes randomly distribute in the slag, some of which tend to aggregate together and grow up. The average size of the particles is about $10 \mu \mathrm{m}$. The distribution of elemental $\mathrm{Fe}$ and $\mathrm{Cu}$ in element mapping implies that the copper has been reduced into metallic $\mathrm{Cu}$ and has dissolved into metallic $\mathrm{Fe}$ to form binary $\mathrm{Fe}-\mathrm{Cu}$ alloy. This could be understood by the theory of solid solution, as proposed by Hume-Rothery et al. ${ }^{43,44)}$ In addition, the separation of elemental $\mathrm{Si}$ from $\mathrm{Fe}$ indicates that the component $\mathrm{SiO}_{2}$ is not reduced during the reduction process, which is determined by the thermodynamics at the experimental temperature. At the same time, the $\mathrm{Fe}-\mathrm{Cu}$ alloy is surrounded by elemental $\mathrm{Ca}, \mathrm{Si}, \mathrm{Mg}$ and $\mathrm{Al}$, which suggests the generation of more complicated phases.

\subsection{Assessment on Iron-extracting from Nickel Slag by Aluminum Dross}

\subsubsection{Analysis on the Reduced Product}

Recovery degree of iron and copper is characterized by Eqs. (10)-(11).

$$
\begin{array}{r}
R_{\mathrm{Fe}}=\frac{M_{\mathrm{RP}} \times w(\mathrm{Fe})}{M_{\mathrm{NS}} \times w(\mathrm{TFe})_{\mathrm{NS}}} \times 100 \% \\
R_{\mathrm{Cu}}=\frac{M_{\mathrm{RP}} \times w(\mathrm{Cu})}{M_{\mathrm{NS}} \times w(\mathrm{Cu})_{\mathrm{NS}}} \times 100 \%
\end{array}
$$

where $R_{\mathrm{Fe}}$ and $R_{\mathrm{Cu}}$ are the recovery degree of $\mathrm{Fe}$ and $\mathrm{Cu}$, respectively (\%), $M_{\mathrm{RP}}$ is the mass of reduction product $(\mathrm{kg})$, $w(\mathrm{Fe})$ and $w(\mathrm{Cu})$ are the weight fractions of $\mathrm{Fe}$ and $\mathrm{Cu}$ in reduced product, respectively (\%), $M_{\mathrm{NS}}$ is the mass of nickel slag $(\mathrm{kg})$ and $w(\mathrm{TFe})_{\mathrm{NS}}$ and $w(\mathrm{Cu})_{\mathrm{NS}}$ are the weight fractions of total $\mathrm{Fe}$ and $\mathrm{Cu}$ in nickel slag, respectively (\%).

Although the droplets dispersed in slag or adhered to the inner surface of crucible are difficult to be collected, the visible droplets together with iron ingot are included in the chemical analysis. After reaction for the determined time, the quenched slag samples are grinded into powders, and magnetic separation is adopted to separate the $\mathrm{Fe}-\mathrm{Cu}$ alloy from the slag waiting for the further analysis. Figure 9 shows the dependence of recovery degree of iron and

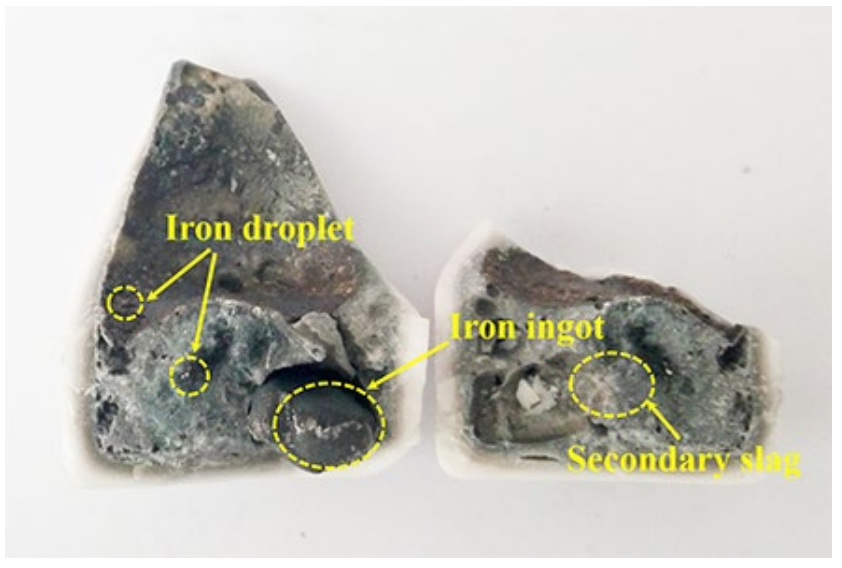

Fig. 7. Images of the reduced product and secondary slag after reduction. (Online version in color.)
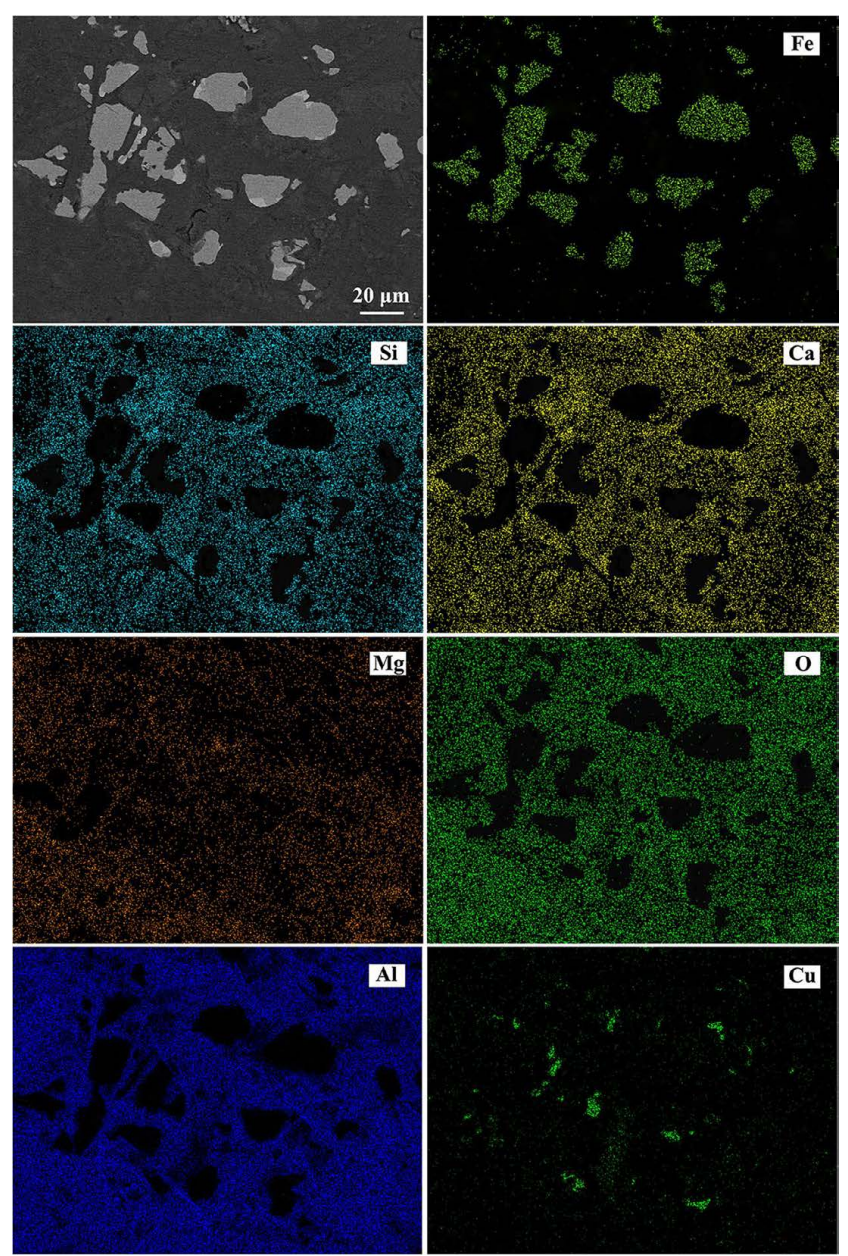

Fig. 8. Slag microstructure after reduction reaction for $120 \mathrm{~min}$ (Online version in color.)

copper on reaction time. It increases evidently in the former 10 min, followed by a slow evolution then. Also, compared with $\mathrm{Fe}, \mathrm{Cu}$ recovery degree is much higher at the same reaction time. For instance, it is $70.56 \%$ and $60.33 \%$ for $\mathrm{Cu}$ and $\mathrm{Fe}$ at $5 \mathrm{~min}$, respectively, which can be originated from the different reaction potentials of oxides $\mathrm{Cu}_{2} \mathrm{O}$ and ' $\mathrm{FeO}$ ' with metallic Al. $\Delta G^{\theta}$ for the related two aluminothermic reactions is $-486.8 \mathrm{~kJ} \cdot \mathrm{mol}^{-1}$ and $-324.5 \mathrm{~kJ} \cdot \mathrm{mol}^{-1}$, respectively. As a consequence, iron and copper in nickel slag could be well reduced by aluminum dross after reaction time 
of $120 \mathrm{~min}$. The recovery degree of these two elements is $94.35 \%$ and $97.89 \%$, respectively.

Chemical compositions of the reduced product at different reaction time are analyzed by XRF. The results shown in Table 4 indicate that the reduced product from the current process is the crude $\mathrm{Fe}-\mathrm{Cu}-(\mathrm{Ni})$ alloy. It's of particular concern that, the change in chemical compositions of the alloy is negligible with reaction time increasing from 5 to $120 \mathrm{~min}$. The content of sulfur in the alloy is lower than $0.03 \mathrm{wt} \%$, which demonstrates the reduced product of $\mathrm{Fe}-$ $\mathrm{Cu}-(\mathrm{Ni})$ alloy has a higher purity. As the studies by Liang et al., the main constituents of weathering resistant steel are

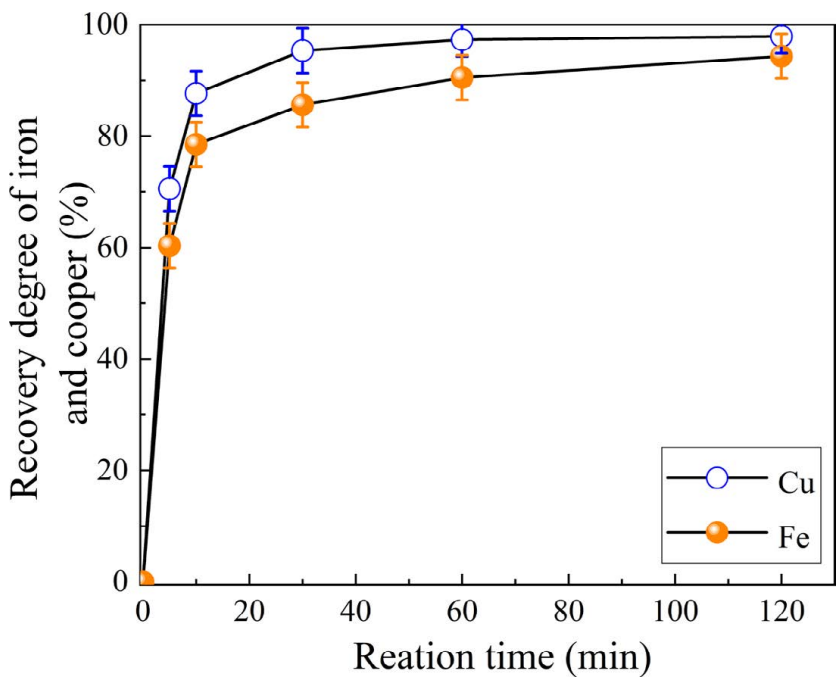

Fig. 9. Dependence of recovery degree of iron and copper on reaction time. (Online version in color.)

Table 4. Chemical compositions of the reduced product (wt $\%)$.

\begin{tabular}{ccccc}
\hline \multirow{2}{*}{$\begin{array}{c}\text { Reaction time } \\
(\text { min })\end{array}$} & \multicolumn{4}{c}{ Elements } \\
\cline { 2 - 5 } & $\mathrm{Fe}$ & $\mathrm{Cu}$ & $\mathrm{Ni}$ & $\mathrm{S}$ \\
\hline 5 & 99.47 & 0.50 & 0.02 & 0.01 \\
10 & 99.49 & 0.48 & 0.02 & 0.01 \\
30 & 99.49 & 0.48 & 0.02 & 0.01 \\
60 & 99.49 & 0.46 & 0.03 & 0.02 \\
120 & 99.50 & 0.44 & 0.03 & 0.03 \\
\hline
\end{tabular}

(a)

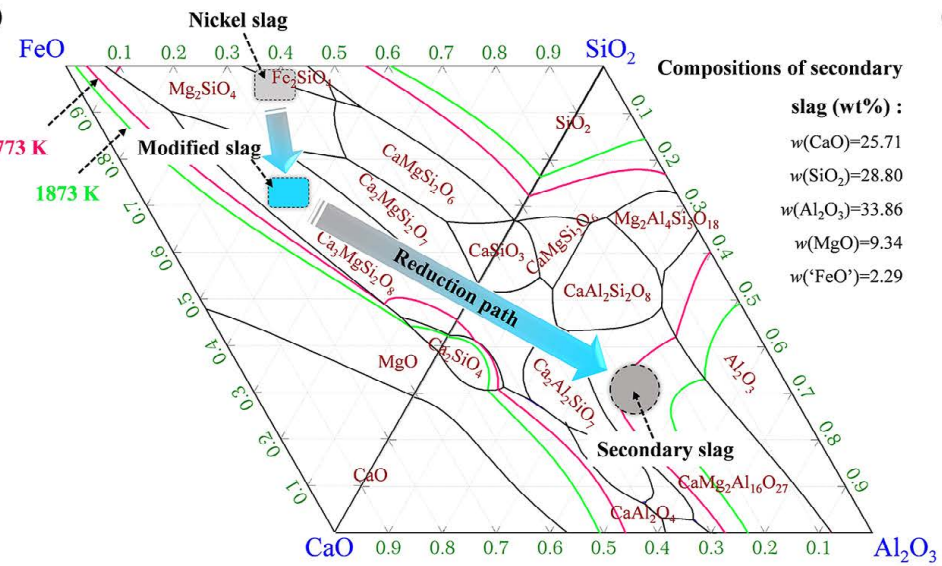

$\mathrm{Fe}, \mathrm{Cu}$ and Ni, therefore, the produced alloy may be utilized as a raw material in making weathering resistant steel. ${ }^{45-47)}$

\subsubsection{Secondary Slag Stabilization}

Given the presence of other components as drawbacks, hazardous element in secondary slag is mainly $\mathrm{Cu}$. In the course of reduction process, about $97.89 \mathrm{wt} \% \mathrm{Cu}$ has transferred to the crude $\mathrm{Fe}-\mathrm{Cu}-(\mathrm{Ni})$ alloy, and the content of the copper left in secondary slag is only about $0.03 \mathrm{wt} \%$. Therefore, the clean slag could be used as the raw materials in cement industries or glass-ceramic productions. ${ }^{48,49)}$ Furthermore, the changes in slag compositions result in the generation of more complicated phases, which signifies a higher slag stabilization. Figures 10(a) and 10(b) show the evolution of slag compositions and mineral phases with reduction process, respectively. In the quasi-quaternary $\mathrm{CaO}-\mathrm{SiO}_{2}-\mathrm{FeO}-\mathrm{Al}_{2} \mathrm{O}_{3}(-9 \mathrm{wt} \% \mathrm{MgO})$ slag system, the dominant phases of slag have transited from merwinite $\left(\mathrm{Ca}_{3} \mathrm{MgSi}_{2} \mathrm{O}_{8}\right)$, gehlenite $\left(\mathrm{Ca}_{2} \mathrm{Al}_{2} \mathrm{SiO}_{7}\right)$ to $\mathrm{CaMg}_{2} \mathrm{Al}_{16} \mathrm{O}_{27}$ phase, which is the primary phase of secondary slag. What's more, the compositions of secondary slag in the center of crucible have been detected and shown in the figure. As shown in Fig. 10(b), the main phases of secondary slag are confirmed as $\mathrm{CaMg}_{2} \mathrm{Al}_{16} \mathrm{O}_{27}$, anorthite $\left(\mathrm{CaAl}_{2} \mathrm{Si}_{2} \mathrm{O}_{8}\right)$, gehlenite $\left(\mathrm{Ca}_{2} \mathrm{Al}_{2} \mathrm{SiO}_{7}\right)$, spine $\left(\mathrm{MgAl}_{2} \mathrm{O}_{4}\right)$ and akermanite $\left(\mathrm{Ca}_{2} \mathrm{MgSi}_{2} \mathrm{O}_{7}\right)$. Additionally, different from the modified slag, FeO peaks in secondary slag have disappeared, which signifies the complete reduction reaction. Compared with the iron-bearing phases, the stronger attraction of cations $\left(\mathrm{Ca}^{2+}\right.$ and $\left.\mathrm{Mg}^{2+}\right)$ and orthosilicate (and aluminate) anions in these produced phases leads to the more stable structure and the higher stabilization of secondary slag. ${ }^{34,35)}$

\section{Conclusions}

The approach of recycling nickel slag by aluminum dross is studied, and the processes of network modification and reduction are investigated successively. The following conclusions can be drawn based on the experimental results.

(1) Thermodynamics analysis suggests that $\mathrm{CaO}$ should be the optimum modifier over the oxides $\mathrm{MgO}$ and $\mathrm{Al}_{2} \mathrm{O}_{3}$ to adjust nickel slag. Basicity of the modified slag is determined as 1.0 upon the $a\left({ }^{\prime} \mathrm{FeO}\right.$ ') and the melting points of initial and secondary slags. Element mapping analysis of

Fig. 10. Evolution of (a) slag compositions and (b) mineral phases with the reduction process. (Online version in color.)

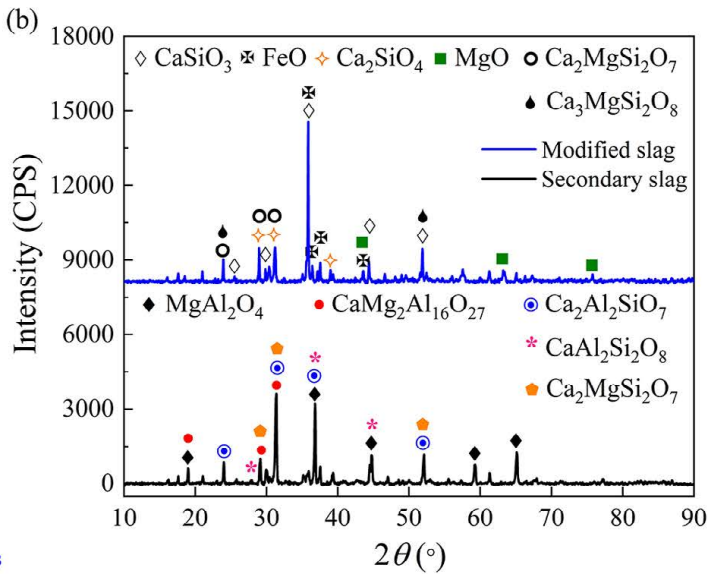


modified slag shows that ' $\mathrm{FeO}$ ' has been separated from the structure of fayalite and hortonolite, which is helpful to the further reduction of ' $\mathrm{FeO}$ '.

(2) Composition analysis on metal phase shows that copper has been reduced into metallic $\mathrm{Cu}$ and has dissolved into metallic iron to form $\mathrm{Fe}-\mathrm{Cu}$ alloy. After reaction time of $120 \mathrm{~min}$, the recovery degree of these two elements is $94.35 \%$ and $97.89 \%$, respectively.

(3) With reduction process, the dominant phases of secondary slag have transited from merwinite $\left(\mathrm{Ca}_{3} \mathrm{MgSi}_{2} \mathrm{O}_{8}\right)$, gehlenite $\left(\mathrm{Ca}_{2} \mathrm{Al}_{2} \mathrm{SiO}_{7}\right)$ to $\mathrm{CaMg}_{2} \mathrm{Al}_{16} \mathrm{O}_{27}$ phase. Compared with the iron-bearing phases, the main phases of secondary slag have the more stable structure, leading to a higher stabilization of secondary slag.

\section{Acknowledgements}

This work was supported by the National Natural Science Foundation of China [Grant numbers 51774072, 51574066, 51574065 and 51774073] and the National Key R\&D Program of China [Grant numbers 2017YFB0304201, 2017YFB0304203 and 2016YFB0300602].

\section{REFERENCES}

1) W. Ni, Y. Jia, F. Zheng, Z. J. Wang and M. J. Zheng: J. Univ. Sci. Technol. Beijing, 32 (2010), 975 (in Chinese).

2) C. F. Zhang, H. X. Liu, D. L. Zhong and D. W. Zeng: Chin. J. Nonferr. Met., 9 (1999), 805 (in Chinese).

3) X. M. Li, G. Xie, J. X. Zhao and Y. R. Cui: Nonferr. Met., 12 (2015), 51 (in Chinese).

4) G. H. Sheng and J. P. Zhai: Met. Mine, 10 (2005), 68.

5) W. L. Kepplinger and T. Tappeiner: Waste Manag. Res., 30 (2012), 450 .

6) G. Q. Li and M. X. Guo: Waste Biomass Valoriz., 5 (2014), 317.

7) B. Gorai, R. K. Jana and Premchand: Resour. Conserv. Recycl., 39 (2003), 299.

8) S. Roy, A. Datta and S. Rehani: Int. J. Miner. Process., 143 (2015), 43.

9) Y. P. Xiao, Y. X. Yang, J. V. D. Berg, J. Sietsma, H. Agterhuis, G. Visse and D. Bol: Hydrometallurgy, 140 (2013), 128.

10) Z. Q. Guo, J. Pan, D. Q. Zhu and F. Zhang: J. Clean. Prod., 199 (2018), 891.

11) C. M. Du, C. Shang, X. J. Gong, T. Wang and X. G. Wei: Waste Manag., 77 (2018), 373.

12) B. J. Zhang, L. P. Niu, T. A. Zhang, Z. Q. Li, D. L. Zhang and C. Zheng: ISIJ Int., 57 (2017), 775.

13) K. Binnemans, P. T. Jones, B. Blanpain, T. V. Gerven, Y. X. Yang, A. Walton and M. Buchert: J. Clean. Prod., 51 (2013), 1.

14) J. H. Heo, Y. Chung and J. H. Park: J. Clean. Prod., 137 (2016), 777.

15) Z. Sun, Y. P. Xiao, H. Agterhuis, J. Sietsma and Y. X. Yang: J. Clean. Prod., 112 (2016), 2977.

16) D. Zhao, G. Q. Li, H. H. Wang and J. H. Ma: ISIJ Int., 57 (2017), 2131.

17) Y. Q. Zhao, T. C. Sun, H. Y. Zhao, X. H. Li and X. P. Wang: ISIJ Int., 58 (2018), 1768

18) Y. Y. Cao, T. C. Sun, J. Kou, C. Y. Xu and E. X. Gao: J. Wuhan
Univ. Technol., 32 (2017), 517.

19) W. Ni, M. S. Ma, Y. L. Wang, Z. J. Wang and F. M. Liu: J. Univ. Sci. Technol. Beijing, 31 (2009), 163 (in Chinese).

20) P. Sarfo, G. Wyss, G. J. Ma, A. Das and C. Young: Miner. Eng., 107 (2017), 8 .

21) B. Li, Z. G. Ding, Y. G. Wei, S. W. Zhou and H. Wang: Mater. Trans., 59 (2018), 1180

22) Y. Wang, R. Zhu, Q. Z. Chen, G. S. Wei, S. Y. Hu and Y. G. Guo: ISIJ Int., 58 (2018), 2191.

23) Y. Y. Shen, M. Chen, Y. Y. Zhang, X. Q. Xu, G. Z. Li and X. Y. Du: Steel Res. Int., 89 (2018), 1700300.

24) J. Y. Hwang, X. Huang and Z. Xu: J. Miner. Mater. Charact. Eng., 5 (2006), 47.

25) H. N. Yoshimura, A. P. Abreu, A. L. Molisani, A. C. de Camargo, J. C. S. Portela and N. E. Narita: Ceram. Int., 34 (2008), 581.

26) L. Jiang, M. F. Qiu, Y. D. Ding, N. Su and Q. Yao: Chin. J. Nonferr. Met., 22 (2012), 3555 (in Chinese).

27) T. Harada, H. Hirata, T. Arai, T. Toh and T. Yamada: ISIJ Int., 58 (2018), 1934.

28) T. Harada, H. Hirata, T. Arai, T. Toh and C. Shuto: ISIJ Int., 58 (2018), 1943.

29) M. Halmann, A. Frei and A. Steinfeld: Energy, 32 (2007), 2420.

30) V. M. Sokolov, V. D. Babyuk, Y. A. Zhydkov and Y. Y. Skok: Miner. Eng., 21 (2008), 143.

31) G. Z. Zhang, N. Wang, M. Chen and H. Li: Steel Res. Int., 89 (2018), 1800272.

32) G. Z. Zhang, N. Wang, M. Chen and Y. Wang: Steel Res. Int., 89 (2018), 1800273

33) C. Y. Sun, X. H. Liu, J. Li, X. T. Yin, S. Song and Q. Wang: ISIJ Int., 57 (2017), 978

34) Y. S. Lee, D. J. Min, S. M. Jung and S. H. Yi: ISIJ Int., 44 (2004), 1283.

35) S. Lee and D. J. Min: Steel Res. Int., 89 (2018), 1800055.

36) Z. Q. Guo, D. Q. Zhu, J. Pan, T. J. Wu and F. Zhang: Metals, 6 (2016), 86

37) L. N. Zhang, L. Zhang, M. Y. Wang, Y. C. Che and Z. T. Sui: Acta Phys. Chim. Sin., 24 (2008), 1540

38) Y. Li and W. B. Dai: J. Clean. Prod., 175 (2018), 176

39) F. Lian, L. J. Ma and K. C. Chou: J. Clean. Prod., 143 (2017), 549.

40) C. W. Bale, A. D. Pelton, W. T. Thompson, G. Eriksson, K. Hack, P. Chartrand, S. A. Decterov, I.-H. Jung, J. Melançon and S. Petersen: The FactSage Thermochemical Database System Home Page, http:// www.factsage.com, (accessed 2019-03-31).

41) J. M. Park, C. H. Keum, J. W. Son and Y. K. Shin: Steelmaking Conf. Proc., Vol. 77, Iron and Steel Society, Warrendale, PA, (1994), 461.

42) J. X. Chen: Handbook of Common Figures, Tables and Data for Steelmaking, 2nd ed., ed. by X. F. Liu, Metallurgical Industry Press, Beijing, (2010), 646 (in Chinese).

43) W. Hume-Rothery and G. V. Raynor: The Structure of Metals and Alloys, Institute of Metals, London, (1962), 246.

44) Z. Q. Guo, D. Q. Zhu, J. Pan and F. Zhang: J. Clean. Prod., 187 (2018), 910 .

45) C. F. Liang and W. T. Hou: Weathering resistant steel, Patent CN1109772C, (2003), (in Chinese).

46) F. M. Song, D. H. Wen, Z. G. Li, X. P. Hu, A. Yang and J. Y. Li: Highly corrosion-resistant, high strength, Al-containing weathering steel plate and process of manufacturing same, Patent US20150354041A1, (2015).

47) GB/T 4171-2008: 2008, Atmospheric corrosion resisting structural steel (in Chinese).

48) W. Holand and G. H. Beall: Glass Ceramic Technology, 2nd ed., John Wiley \& Sons, Hoboken, (2012), 75.

49) H. F. W. Taylor: Cement Chemistry, 2nd ed., Thomas Telford Services, London, (1997), 187. 